\title{
The Effect of Replacing Dried Meal Worm with Soybean Meal on Growth Performance and Carcass Characteristics of Broiler Chickens
}

\author{
Navid Naderi Boroojerdi ( $\sim$ naderi.navid1364@gmail.com ) \\ Islamic Azad University Birjand Branch https://orcid.org/0000-0002-2901-476X \\ Mostafa Rajabzadeh \\ University of Asia: Asia University
}

\section{Research Article}

Keywords: Broiler chickens, Carcass characteristics, Dried mealworm, Soybean meal

Posted Date: September 16th, 2021

DOI: https://doi.org/10.21203/rs.3.rs-782326/v1

License: (c) (i) This work is licensed under a Creative Commons Attribution 4.0 International License. Read Full License 


\section{Abstract}

An experiment was conducted on 240 one-day old male (Ross308) chicken to the effect of substitution of dried mealworm (Tenebrio molitor) with soybean meal on growth performance and carcass characteristics broiler chicks. Chicks fed in a completely randomized design with 4 replicate cages (12 birds per cage). Five dietary treatments used: 1- Control treatment: Basal diet based on corn-soybean meal without adding dried mealworm, 2- Replacement of $5 \%$ dried mealworm with soybean meal in the base diet, 3 - Replacement of $10 \%$ dried mealworm with soybean meal in the base diet, 4- Replacement of $15 \%$ dried mealworm with soybean meal in the base diet and 5Replacement of $20 \%$ dried mealworm with soybean meal in the base diet. The results of the experiment showed that 3rd and 4th treatments with a substitution of 10 and 15 percent showed a higher mean weight gain and a daily gain, but their feed intake was lower comparing other treatments, and finally, the feed conversion ratio showed a significant decrease with respect to control treatment using these replacement levels. At 21 and 42 days of age, carcass yield and relative weight of the breasts showed significant increases in treatments 3 and 4 , and other characteristics of chicken carcasses were not affected by the test treatments. The experiment showed that replacing soybean meal with $10 \%$ and $15 \%$ worm powder significantly improved the performance of broiler chickens, but no significant difference was found between the two levels.

\section{Introduction}

The International Feed Industry Federation (IFIF) announced that the world population maybe increased to more than 10 billion people by the year 2050 (FAO 2013). Moreover, it is expected that consumption of animal protein will be doubled for mentioned population (FAO 2013). For poultry meat, the expected growth of consumption from 2010 to 2050 is $173 \%$ (FAO 2013). Dietary sources of protein are one of the essential nutrients in poultry nutrition. These resources, in addition to being an important part of the poultry diet, are also considered the most expensive portion of the diet (Ballitoc and Sun. 2013). Oily meal is the most important source among plant protein origin.

Currently, the Soybean meal is the most important oily meal that is used in the formulation of diets of broilers and laying hens which is due to the quantity and quality of its protein as well as the appropriate amino acid composition of this meal (Biasato et al. 2016). However, in Asia, the shortage of availability of soybean meal for livestock and poultry feed is as the result of the significant amount of soybeans consumed as human food and the low soybean production capacity in the tropics due to insufficient agricultural facilities and lack of suitable crops (Veldkamp et al. 2012). According to that, the most of the costs in the poultry industry are related to feed, it is important to try to find a suitable alternative to soybean meal (Biasato et al. 2016). Insects are the third generation of proteins in the world. More than 10 million of insect species have been identified, which account for a half of all creatures in earth (Hussain et al. 2017). Among of them, approximately 1,500 species of insects are known to be an edible protein source for humans and animals (Hussain et al. 2017). In between, Mealworm (Tenebrio molitor), is a good food source for small mammals and poultry (Hussain et al. 2017). Nutritional value of mealworms varies depending on species and developmental stage. These worms are rich in protein, fats, essential aminoacids, and vitamins or minerals (Rumpold and Schlüter. 2013). Insects, in general, contain a higher amount in lysine and threonine which are deficient in most commonly used cereal as wheat, rice, cassava and maize but have the lower amount of amino acids, methionine and cysteine (Selaledi et al. 2020). The small size of the worms is ideal for small reptiles and young birds as a dietary supplement (Bovera et al. 2016 Hussein et al. 2017). Because these worms feed on bran, barley, soy, are the best food supplements for raising chickens, turkeys, quails and are the result of bird growth and production of completely natural and quality meat (Loponte. 2017; Schiavone et al. 2016). Some authors evaluated the effects of Tenebrio molitory (TM) meal utilization on growth performance (Ballitoc and Sun. 2013; Bovera et al. 
2015; Bovera et al. 2016), haematochemical profile (Bovera et al. 2015), and carcass characteristics (Ballitoc and Sun. 2013; Bovera et al. 2016) of broilers, While the rest of their research focused on the morphology of the intestine and histological features in free-range chickens fed diets including TM meal (Biasato et al., 2016). The economic production parameters of mealworms include their ability to convert organic matter into protein more efficiently compared with their animal counterparts, less space and water needed (Belluco et a. 2013), and the lower environmental impact of insect-based products compared with animal-based products (Dobermann et al. 2017), have a nutrient profile similar to fish meat, so they can contribute to more balanced human and animal diets convert often unused and globally abundantly available organic residues, such as straw, food waste, green biomass, faeces, and manure into biomass efficiently commercial production capability (Ramos-Elorduy et al. 2002). In other words, food production systems have a great impact on environmental water changes. We need to produce more food for more people in less places. Research shows that insects can be used as a source of protein for livestock, poultry and even humans. By producing less greenhouse gases, which play a major role in global warming, this important phenomenon can be prevented and the planet's water resources will be better preserved (Springmann et al. 2017).

The aim of this article is to evaluate the effect of partial substitution of soybean meal with mealworm on growth performance and carcass characteristics of Ross broiler chickens.

\section{Materials And Methods}

\section{Animal, management, and diets}

A total of $\mathbf{2 4 0}$ one day old male chicks (Ross 308) with an initial BW of $41.57 \pm 0.4 \mathrm{~g}$ were provided from local commercial hatchery (Broiler Breeder of Ghazvin Complex Productive Co., Iran). Chickens were randomly assigned to 5 treatment groups with 4 replications of 12 chicks. Each group was fed for 42 days with isocaloric and isonitrogenous diets (Table 1 and2) that were formulated based on standard recommendation (Ross 2007). Five dietary treatments used: 1- Control treatment: Basal diet based on corn-soybean meal without adding dried mealworm, 2-Replacement of $5 \%$ dried mealworm with soybean meal in the base diet, 3 - Replacement of $10 \%$ dried mealworm with soybean meal in the base diet, 4- Replacement of $15 \%$ dried mealworm with soybean meal in the base diet and 5 - Replacement of $20 \%$ dried mealworm with soybean meal in the base diet. Birds were provided with known amounts of feed ad libitum. Ethics approval for the animal trials was obtained from the Animal Ethics Committee, Birjand Branch, Islamic Azad University, Birjand, Iran. The chicks had free access to water. Birds were maintained at a brooding temperature of $32{ }^{0} \mathrm{C}$ for 5 day and then the environmental temperature was gradually reduced to $22{ }^{\circ} \mathrm{C}$. During the experiment, light was provided continuously ( 24 hours). Routine vaccination and health care was given when it was necessary.

\section{Sample collection and measurements}

The chickens in each pen were also weighed at the beginning of the experiment and tried to keep the average of each pen almost close to each other. At the end of each week of the trial, after 2 hours of starving, the chickens were weighed using a digital scale with an accuracy of $0.01 \mathrm{~g}$. Then, the average body weight of a bird was calculated according to the number of birds in each unit. To calculate weight gain at each time point, the difference in body weight at the end and beginning of the period was determined. By dividing the weight by 7 , the daily weight gain (DWG) was calculated. Feed intake (FI) was calculated from the difference between feed given during the week and return feed. Feed conversion ratio (FCR) was calculated by dividing feed consumption by body weight gain. 
Two birds from each pen were randomly selected for estimation of carcass characteristics on day 21 and 42 of the trail. Chickens slaughtered by displacing the neck. Abdominal fat, spleen, drumsticks, and breast were separated and weighed; the empty or edible carcass weights were recorded (Shabani et al. 2015). Also thighs were weighed. Relative weights (RW) were calculated: weight of cut or organ (g) / $100 \mathrm{~g}$ of body weight (Shabani et al. 2015). Broiler digestive enzymes were gradually completed by the end of three weeks. Therefore, to determine the differences of the effect of diet experiment by age 42 days, slaughter was performed at the end of 21 days (León et al. 2014).

\section{Statistical analysis}

Obtained data were subjected to analysis of variance procedures appropriate for a completely randomized design and analyzed by one-way ANOVA using the General Linear Model procedures of SAS (SAS Inst. Inc., Cary, NC). Mean separation was carried through using Duncan post hoc test. All significance level was set at $P<0.05$.

\section{Results}

The results of the WG and DWG were shown in the tables 3 and 4. During The first weeks of testing, Only the replacement of $10 \%$ and $15 \%$ of soybean meal with mealworm significantly $(P<0.05)$ improved the WG and DWG gain of the tested chickens and Levels of 5 and $20 \%$ replacement did not have a significant effect on the WG and DWG gain ( $P>0.05$ ). But in the other weeks of testing Replacement of $5 \%$ and $20 \%$ of soybean meal with mealworm compared to the control diet caused a significant increase in the WG and DWG gain. But compared to the treatments where the replacement level was $10 \%$ and $15 \%$, this increase was less. The results showed that replacement of $10 \%$ and $15 \%$ of soybean meal mealworm compared to control diet, improved $(P<0.05)$ the WG and DWG gain. Due to the price difference between these two protein sources, it can have a significant effect on the cost of the ration. But no significant difference between the two alternative levels of $10 \%$ and $15 \%$ was observed $(P>0.05)$.

The results related to the average FI were shown in the table5. Results showed that the highest FI numerically was observed in chickens fed with control treatment

Replacement of mealworm with soybean meal in the diet only at the level of $15 \%$ significantly decreased daily $\mathrm{FI}$ $(P<0.05)$. Other replacement levels, however, numerically reduced FI but the difference with control treatment was not significant $(P<0.05)$.

The results related to FCR were shown in the table 6. In the third week of the experiment, the highest FCR numerically was observed in the control treatment but the difference was significant with treatments with replacement of 15 and $10 \%$ of mealworm with soybean meal $(P<0.05)$. In the fourth week, control and treatment 4 caused the highest and lowest FCR, respectively, and their differences with other experimental treatments were significant $(P<0.05)$. At the fifth and sixth weeks of the experiment, the control treatment showed the highest FCR and its difference with other experimental treatments was significant $(P<0.05)$.

Treatment 4 with a replacement level of $15 \%$ also showed the lowest FCR. The difference with other experimental treatments except treatment3 was significant $(P<0.05)$. The results showed that level of replacement of $15 \%$ mealworm with soybean meal could improve performance in broilers and reduced the FCR.

The results related to Carcass characteristics at 21 and 42 days were shown in the tables 7 and 8 . At 21 and $42 d$, experimental diets had significant effect on carcass yield $(P<0.05)$. Treatments 3 and 4 had higher carcass yields 
and their differences with other treatments were significant $(P<0.05)$. Between experimental treatments in terms of ratio of thigh weight to live weight was not observed significant difference $(P<0.05)$. The ratio of breast weight to live weight was affected by experimental treatments. Treatments 3 and 4 had higher relative breast weights compared to other treatments and their difference with other treatments was significant $(P<0.05)$. at 21 and $42 d$ the effect of experimental treatments on the relative weight of liver, spleen, heart, pancreas, ventricular adipose tissue and bursa of fabricius was not significant $(P<0.05)$.

\section{Discussion}

High amount of protein, fats, amino acids and mineral content were found in T. molitor; consequently, it can easily be used in the poultry ration (Aguilar-Miranda et al. 2002). The existence of chitin in insects' meal has the potential to improve poultry health as the result of decreasing populations of intestinal Escherichia coli and Salmonella spp., beside it could increase intestinal Lactobacillus spp. The larvae of a darkling beetle are also rich in fiber and fatty acids; thus, it improves digestion (Siemianowska et al. 2013). It can be used as an alternative to antibiotics in the poultry diet when fermented with probiotics (Islam and Yang 2016). Also, chickens that used mealworm in their diet had softer, and to be juicy meat (Khan et al. 2017).

The results of some researchers also showed the positive effects of the use of mealworm in the diet of broilers. Biasatu et al. (2017) used 50, 100 and $150 \mathrm{~g} / \mathrm{kg}$ of yellow swarm larvae in broiler diets. Results showed that mean body weight and daily body weight gain linearly increased with increasing yellow mealworm in the diet. Ballitoc and Sun (2013) and Bovera et al. (2015) reported improved growth performance of broilers using levels of 0 to $100 \mathrm{~g} /$ $\mathrm{kg}$ or $296 \mathrm{~g} / \mathrm{kg}$ mealworm, respectively. Jane et al. (2016) attributed the positive effects of the use of mealworm in the diet to the digestibility of nutrients. They stated that animal protein sources are better accessible than plant sources and their amino acid composition is more balanced. On the other hand, Fink (2002) reported that the amount of unsaturated fatty acids in mealworm is high and when replacing soybean meal with mealworm, the ability to digest fat is maintained. Therefore, the positive effects of replacing mealworm with soybean meal to $15 \%$ can be justified but a lack of significant impact at the $20 \%$ level may be related to the presence of certain factors in soy or mealworm which has not been reviewed yet.

Some researchers have also reported a lack of significant effect of mealworm on broiler performance (Bovera et al. 2016; Cullere et al. 2016). The difference between the results of these tests and the results of the present test may be in the form of usage or the amount of mealworm supplementation.

In this experiment, replacing $15 \%$ of mealworm with soybean meal significantly reduced feed intake $(P>0.05)$. Poultry consume enough feed to meet their needs (Hwangbo and Hong. 2009). According to supplementation of mealworm to the diet of broilers increased the digestibility of nutrients, such as protein and fat and with reference to high amount of energy in mealworm, a smaller amount of this diet, energy and nutrient needs are met and the amount of feed consumption is reduced (Hwangbo and Hong. 2009). The results of several experiments show no effect of supplementation of mealworm in the diet of broilers on carcass characteristics (Biasato et al. 2016; Bovera et al. 2016; Cullere et al. 2016). Positive effect of 15\% replacement of mealworm with soybean meal on carcass percentage and relative breast weight can be attributed to more energy supply, better digestion of nutrients and higher weight average at this level.

\section{Conclusion}


The present research results indicated that substitution of soybean meal in the diet of broilers with mealworm at the level of $15 \%$ can improve growth performance and carcass characteristics. It is better to investigate the effect of replacing dried meal worm with soybean meal on blood parameters and the immune system of broilers in other researchers.

\section{Declarations}

\section{Funding}

Not applicable.

\section{Conflicts of interest/Competing interests}

No potential conflict of interest was reported by the authors.

\section{Availability of data and material}

Not applicable.

\section{Code availability}

Not applicable.

\section{Authors' contributions}

Not applicable

\section{Ethics approval}

The animal experiments have been approved by the Institutional Animal care and use Committee of Birjand Branch, Islamic Azad University and have therefore been performed according to the guidelines for Animal Experimentation at Birjand Branch, Islamic Azad University.

\section{Consent to participate}

Not applicable

\section{Consent for publication}

Not applicable

\section{References}

1. Aguilar-Miranda, E.D., López, M.G., Escamilla-Santana, C. and Barba de la Rosa, A.P., 2002. Characteristics of maize flour tortilla supplemented with ground Tenebrio molitor larvae. Journal of Agricultural and Food Chemistry, 50(1), 192-195.

2. Ballitoc, D.A., and Sun. S., 2013. Ground yellow mealworms (Tenebrio molitor L.) feed supplementation improves growth performance and carcass yield characteristics in broilers. Open Science Repository Agriculture 
3. Belluco, S., Losasso, C., Maggioletti, M., Alonzi, C.C., Paoletti, M.G., and Ricci, A. 2013. Edible insects in a food safety and nutritional perspective: A critical review. Comprehensive Reviews Food Science and Food Safety, 12, 296-313.

4. Biasato, I., Gasco, L., Marco, M. De., Renna, M., Rotolo, L., Dabbou, S., Capucchio, M. T., Biasibetti, E., Tarantola, M., Sterpone, L., Cavallarin, L., Gai, F., Pozzo, L., Bergagna, S., Dezzutto, D., Zoccarato, I., and Schiavone, A., 2018. Yellow mealworm larvae (Tenebriomolitor) inclusion in diets for male broiler chickens: effects on growth performance, gut morphology, and histological findings. Poultry Science, 97,540-548.

5. Biasato, I., Marco, M. De., Rotolo, L., Renna, M., Dabbou, S., Capucchio, M. T., Biasibetti, E., Tarantola, M., Costa, P., Gai, F., Pozzo, L., Dezzutto, D., Bergagna, S., Gasco, L. and Schiavone, A., 2016. Effects of dietary Tenebrio molitor meal inclusion in free-range chickens. Animal Physiology Animal Nutrient 100(6), 1104-1112.

6. Bovera, F., Loponte R., Marono, S., Piccolo G., Parisi, G., laconisi, V., Gasco, L., and Nizza, A., 2016. Use of Tenebrio molitor larvae meal as protein source in broiler diet: effect on growth performance, nutrient digestibility and carcass and meat traits. Journal of Animal Science, 94,639-647

7. Bovera, F., Piccolo, G., Gasco, L., Marono, S., Loponte, R., Vassalotti, G., Mastellone, V., Lombardi, P., Attia, Y. A., and Nizza, A., 2015. Yellow mealworm larvae (Tenebrio molitor, L.) as apossible alternative to soybean meal in broiler diets. British Poultry Science, 56,569-575.

8. Cullere, M., Tasoniero, G., Giaccone, V., Miotti-Scapin, R., Claeys, E., De Smet, S., and Dalle Zotte, A., 2016. Black soldier fly as dietary protein source for broiler quails: apparent digestibility, excreata microbial load, feed choice, performance, carcass and meat traits. The Animal Consortium, 10, 1923-1930.

9. Dobermann, D., Swift, J.A., and Field, L.M., 2017. Opportunities and hurdles of edible insects for food and feed. Nutrient Bullten, 42, 293-308.

10. FAO (Food and Agriculture Organization of the United Nations), 2013. Edible insects - future prospects for food and feed security. FAO Forestry Paper 171:IX.

11. Finke, M. D., 2002. Complete nutrient composition of commercially raised invertebrates used as food for insectivores. Zoo Biology, 21,269-285

12. Hussain, I., Khan, S., Sultan, A., Chand, N., Khan, R., Alam, W., and Ahmad, N., 2017. Meal worm (Tenebrio molitor) as potential alternative source of protein supplementation in broiler. International Journal of Biosciences, 10, 255-262.

13. Hwangbo, J., and Hong, E. C., 2009. Utilization of house fly maggots, a feed supplement in the production of broiler chickens. Journal of Environ and Biology, 30, 609-614.

14. Islam, M.M. and Yang, C.J., 2016. Efficacy of mealworm and super mealworm larvae probiotics as an alternative to antibiotics challenged orally with Salmonella and E. coli infection in broiler chicks. Poultry Science, 96(1), 27-34.

15. Jin, X. H., Heo, P. S., Hong, J. S., Kim, N. J., and Kim, Y. Y., 2016. Supplementation of dried mealworm (Tenebrio molitor larva) on growth performance, nutrient digestibility and blood profiles in weaning pigs. Asian Australas Journal of Animal Science, 29(7), 979-986.

16. Khan, S., Khan, R. U., Alam, W. and Sultan, A., 2017. Evaluating the nutritive profile of three insect meals and their effects to replace soya bean in broiler diet. Journal of Animal Physiology and Animal Nutrition, 102(2), e662-e668.

17. Loponte, R., Nizza, S., Bovera, F., De Riu, N., Fliegerova, K., Lombardi, P., Vassalotti, G., Mastellone, V., Nizza, A., and Moniello, G., 2017. Growth performance, blood profiles and carcass traits of Barbary partridge (Alectoris 
barbara) fed two different insect larvae meals (Tenebrio molitor and Hermetia illucens). Reserch Veterinary Science, 115,183-188.

18. Milagro León, T. M.Sc., Gerardo Garrido, G. M.Sc., María Castañeda, D. TSU., and Emma Rueda, de A., 2014. Early feeding to modify digestive enzyme activity in broiler chickens. Revista MVZ Córdoba, 19, 4316-4327.

19. NRC. 1994. Nutrient requirements of poultry. Washington (DC): National Academic Press.

20. Ramos-Elorduy, J., González, E.A., Hernández, A.R. and Pino, J.M., 2002. Use of Tenebrio molitor (Coleoptera: Tenebrionidae) to recycle organic wastes and as feed for broiler chickens. Journal of Economic Entomology, 95(1), 214-220.

21. Rumpold, B.A., and Schlüter, O.K., 2013. Nutritional composition and safety aspects of edible insects. Molecular Nutrition and Food Research, 57(5), 802-823.

22. S'anchez-Muros, M. J., Barroso, F. G., and Manzano-Agugliaro, F., 2014. Insect meal as renewable source of food for animal feeding: a review. Journal Clean Product, 65, 16-27.

23. Schiavone, A., Cullere, M., De Marco, M., Meneguz, M., Biasato, I., Bergagna, S., Dezzutto, D., Gai, F., Dabbou, S., Gasco, L., and Dalle Zotte, L., 2016. Partial or total replacement of soybean oil by black soldier fly larvae (Hermetia illucens L.) fat in broiler diets: effect on growth performances, feedchoice, blood traits, carcass characteristics and meat quality. Italian Journal of Animal Scienc, 16, 93-100.

24. Selaledi, L., Mbajiorgu, C. A., and Mabelebele, M., 2020. The use of yellow mealworm (T. molitor) as alternative source of protein in poultry diets: a review. Tropical Animal Health and Production, 52, 7-16.

25. Shabani, S., Seidavi, A., Asadpour, L., and Corazzin, M., 2015. Effect of physical form of diet and intensity and duration of feed restriction on the growth performance, blood variables, microbial flora, immunity, and carcass and organ characteristics of broiler chickens. Livestock Science, 180, 150-157.

26. Siemianowska, E., Kosewska, A., Aljewicz, M., Skibniewska, K.A., Polak-Juszczak, L., Jarocki, A. and Jędras, M., 2013. Larvae of mealworm (Tenebrio molitor L.) as European novel food. Agricultural Sciences, 4(06), 287.

27. Springmann, M., Mason-D'Croz, D., Robinson, S., Wiebe, K., Godfray, H.C.J., Rayner, M., and Scarborough, P., 2017. Mitigation potential and global health impacts from emissions pricing of food commodities. Natioal Climate Chang Journal, 7, 69-74.

28. Veldkamp, T., van Duinkerken, G., van Huis, A., lakemond, C. M. M., Ottevanger, E., Bosch, G., and Van Boekel, M. A. J. S., 2012. Insects as a sustainable feed ingredient in pig and poultry diets - a feasibility study. Wageningen UR Livestock Research, 638-648.

\section{Tables}

Table 1 Ingredients and chemical composition of used diets at (1-21 d) 


\begin{tabular}{|c|c|c|c|c|c|}
\hline Experimental group & Control & $5 \%$ mealworm & $\begin{array}{l}10 \% \\
\text { mealworm }\end{array}$ & $\begin{array}{l}15 \% \\
\text { mealworm }\end{array}$ & $\begin{array}{l}20 \% \\
\text { mealworm }\end{array}$ \\
\hline \multicolumn{6}{|l|}{ Ingredients } \\
\hline \multicolumn{6}{|l|}{ (g/100g as-fed) } \\
\hline Corn & 66.25 & 66.25 & 66.25 & 66.25 & 66.25 \\
\hline Soybean meal & 32.50 & 30.88 & 29.25 & 27.62 & 26.00 \\
\hline Mealworm & 0 & 1.62 & 3.25 & 4.88 & 6.50 \\
\hline Dicalcium phosohate & 0.13 & 0.11 & 0.10 & 0.08 & 0.07 \\
\hline Shell & 0.16 & 0.18 & 0.19 & 0.21 & 0.22 \\
\hline Lysine & 0.10 & 0.10 & 0.10 & 0.10 & 0.10 \\
\hline Methionine & 0.16 & 0.16 & 0.16 & 0.16 & 0.16 \\
\hline Vitamin mineral premix ${ }^{1}$ & 0.50 & 0.50 & 0.50 & 0.50 & 0.50 \\
\hline Na chloride & 0.20 & 0.20 & 0.20 & 0.20 & 0.20 \\
\hline \multicolumn{6}{|l|}{ Calculated analysis } \\
\hline $\begin{array}{l}\text { Metabolizable energy } \\
(\mathrm{MJI} / \mathrm{kg})\end{array}$ & 3000 & 3000 & 3000 & 3000 & 3000 \\
\hline Available phosphorus, g/kg & 5 & 5 & 5 & 5 & 5 \\
\hline Lysine, $\mathrm{g} / \mathrm{kg}$ & 11 & 11 & 11 & 11 & 11 \\
\hline Methionine, $\mathrm{g} / \mathrm{kg}$ & 3.50 & 3.50 & 3.50 & 3.50 & 3.50 \\
\hline \multicolumn{6}{|l|}{ Analysed composition (g/kg) } \\
\hline Crude protein $(\mathrm{N} \times 6.25)$ & 220 & 220 & 220 & 220 & 220 \\
\hline Calcium & 10.20 & 10.20 & 10.20 & 10.20 & 10.20 \\
\hline Fiber & 38.20 & 38.20 & 38.20 & 38.20 & 38.20 \\
\hline
\end{tabular}

Notes: Mineral mix supplied/kg diet: Mn, 55 mg; Zn, 50 mg; Fe, 80 mg; Cu, 5 mg; Se, 0.1 mg; l, 0.18 mg. Vitamins mix supplied/kg diet: vitamin A, 18,000 IU; vitamin D3, 4000 IU; vitamin E, 36 mg; vitamin K3, 4 mg; vitamin B12, 0.03 mg; thiamine, $1.8 \mathrm{mg}$; riboflavin, $13.2 \mathrm{mg}$; pyridoxine, $6 \mathrm{mg}$; niacin, $60 \mathrm{mg}$; calcium pantothenate, $20 \mathrm{mg}$; folic acid, 2 $\mathrm{mg}$; biotin, $0.2 \mathrm{mg}$; choline chloride, $500 \mathrm{mg}$.

Table 2 Ingredients and chemical composition of used diets at (22-42 d) 


\begin{tabular}{|c|c|c|c|c|c|}
\hline Experimental group & Control & $5 \%$ mealworm & $\begin{array}{l}10 \% \\
\text { mealworm }\end{array}$ & $\begin{array}{l}15 \% \\
\text { mealworm }\end{array}$ & $\begin{array}{l}20 \% \\
\text { mealworm }\end{array}$ \\
\hline \multicolumn{6}{|l|}{$\begin{array}{l}\text { Ingredients } \\
\text { (g/100g as-fed) }\end{array}$} \\
\hline Corn & 68.73 & 68.73 & 68.73 & 68.73 & 68.73 \\
\hline Soybean meal & 30 & 28.50 & 27 & 25.50 & 24 \\
\hline Mealworm & 0 & 1.5 & 3 & 4.5 & 6 \\
\hline Dicalcium phosohate & 0.12 & 0.11 & 0.09 & 0.08 & 0.06 \\
\hline Shell & 0.17 & 0.18 & 0.20 & 0.21 & 0.23 \\
\hline Lysine & 0.10 & 0.10 & 0.10 & 0.10 & 0.10 \\
\hline Methionine & 0.18 & 0.18 & 0.18 & 0.18 & 0.18 \\
\hline Vitamin mineral premix ${ }^{1}$ & 0.50 & 0.50 & 0.50 & 0.50 & 0.50 \\
\hline $\mathrm{Na}$ chloride & 0.20 & 0.20 & 0.20 & 0.20 & 0.20 \\
\hline \multicolumn{6}{|l|}{ Calculated analysis } \\
\hline $\begin{array}{l}\text { Metabolizable energy } \\
(\mathrm{MJl} / \mathrm{kg})\end{array}$ & 3100 & 3100 & 3100 & 3100 & 3100 \\
\hline Available phosphorus, g/kg & 4.50 & 4.50 & 4.50 & 4.50 & 4.50 \\
\hline Lysine, g/kg & 10.30 & 10.30 & 10.30 & 10.30 & 10.30 \\
\hline Methionine, $\mathrm{g} / \mathrm{kg}$ & 3.65 & 3.65 & 3.65 & 3.65 & 3.65 \\
\hline \multicolumn{6}{|l|}{ Analysed composition (g/kg) } \\
\hline Crude protein $(\mathrm{N} \times 6.25)$ & 190 & 190 & 190 & 190 & 190 \\
\hline Calcium & 8.45 & 8.45 & 8.45 & 8.45 & 8.45 \\
\hline Fiber & 36.50 & 36.50 & 36.50 & 36.50 & 36.50 \\
\hline
\end{tabular}

Notes: Mineral mix supplied/kg diet: Mn, 55 mg; Zn, 50 mg; Fe, 80 mg; Cu, 5 mg; Se, 0.1 mg; l, 0.18 mg. Vitamins mix supplied/kg diet: vitamin A, 18,000 IU; vitamin D3, 4000 IU; vitamin E, 36 mg; vitamin K3, 4 mg; vitamin B12, 0.03 mg;thiamine, $1.8 \mathrm{mg}$; riboflavin, $13.2 \mathrm{mg}$; pyridoxine, $6 \mathrm{mg}$; niacin, $60 \mathrm{mg}$; calcium pantothenate, $20 \mathrm{mg}$; folic acid, 2 $\mathrm{mg}$; biotin, $0.2 \mathrm{mg}$; choline chloride, $500 \mathrm{mg}$.

Table3 Effect of experimental diets on live weight of broiler chickens (g) 

Age (d)
1
7
14
21
28
35
42

\begin{tabular}{|c|c|c|c|c|c|c|c|}
\hline Experimental diet & Live we & ht (g) & & & & & \\
\hline $1^{1}$ & $41.20^{a}$ & $102.54^{b}$ & $235.25^{c}$ & $585.60^{c}$ & $868.52^{c}$ & $1303.50^{c}$ & $1902.21^{c}$ \\
\hline 2 & $41.35^{a}$ & $103.32^{b}$ & $238.78^{b c}$ & $596.08^{b c}$ & $893.03^{b}$ & $1345.82^{b}$ & $1938.09^{b}$ \\
\hline 3 & $42.06^{a}$ & $109.58^{a}$ & $250.08^{a}$ & $607.21^{a}$ & $913.76^{a}$ & $1363.86^{a}$ & $1998.93^{a}$ \\
\hline 4 & $41.65^{a}$ & $108.23^{a}$ & $249.68^{a}$ & $610.05^{a}$ & $921.36^{a}$ & $1370.14^{a}$ & $2010.07^{a}$ \\
\hline 5 & $42.19^{a}$ & $103.05^{b}$ & $239.43^{b}$ & $597.96^{b}$ & $900.74^{b}$ & $1335.24^{b}$ & $1959.08^{b}$ \\
\hline \pm SEM $^{2}$ & 0.02 & 1.05 & 2.15 & 6.45 & 7.28 & 12.07 & 17.09 \\
\hline
\end{tabular}

P-value

$\begin{array}{lllllll}\text { NS } & 0.0001 & 0.0001 & 0.0001 & 0.0001 & 0.0001 & 0.0001\end{array}$

1: 1- Control treatment: Basal diet based on corn-soybean meal without adding dried mealworm, 2- Replacement of $5 \%$ dried mealworm with Soy meal in the base diet, 3-Replacement of 10\% dried mealworm with Soy meal in the base diet, 4- Replacement of 15 dried mealworm with Soy meal in the base diet and 5- Replacement of $20 \%$ dried mealworm with Soy meal in the base diet.

2: Mean error standard

Column means with common superscripts do not differ $(P>0.05)$.

Table 4 Effect of experimental diets on daily weight gain of broiler chickens $(\mathrm{g} / \mathrm{d})$ 


Age (d) $\quad 1-7 \quad 8-14 \quad 15-21 \quad 22-28 \quad 29-35 \quad 36-42$

\section{Experimental diet Daily weight gain(g/d)}

\begin{tabular}{|c|c|c|c|c|c|c|}
\hline $1^{1}$ & $9.78^{a}$ & $19.04^{b}$ & $40.23^{b}$ & $39.34^{c}$ & $58.45^{c}$ & $67.28^{c}$ \\
\hline 2 & $9.83^{a}$ & $20.57^{b}$ & $43.02^{b}$ & $41.95^{b}$ & $61.72^{b}$ & $71.94^{b}$ \\
\hline 3 & $10.02^{a}$ & $24.02^{\mathrm{a}}$ & $46.86^{a}$ & $44.29^{a}$ & $65.34^{a}$ & $75.14^{\mathrm{a}}$ \\
\hline 4 & $10.08^{a}$ & $23.96^{\mathrm{a}}$ & $45.95^{a}$ & $46.88^{a}$ & $66.08^{a}$ & $77.09^{a}$ \\
\hline 5 & $9.90^{\mathrm{a}}$ & $20.99^{b}$ & $42.94^{b}$ & $41.85^{b}$ & $62.01^{b}$ & $71.61^{b}$ \\
\hline \pm SEM $^{2}$ & 0.15 & 1.27 & 1.35 & 1.43 & 1.56 & 1.83 \\
\hline
\end{tabular}

P-value

NS $\quad \begin{array}{lllll}0.0018 & 0.0001 & 0.0188 & 0.024 & 0.0023\end{array}$

1: 1- Control treatment: Basal diet based on corn-soybean meal without adding dried mealworm, 2- Replacement of $5 \%$ dried mealworm with Soy meal in the base diet, 3-Replacement of $10 \%$ dried mealworm with Soy meal in the base diet, 4- Replacement of 15 dried mealworm with Soy meal in the base diet and 5- Replacement of $20 \%$ dried mealworm with Soy meal in the base diet.

2: Mean error standard

Column means with common superscripts do not differ $(P>.05)$.

Table 5 Effect of experimental diets on feed intake of broiler chickens $(\mathrm{g} / \mathrm{d})$ 


$\begin{array}{llllll}\text { Age }(d) \quad 1-7 & 8-14 & 15-21 & 22-28 & 29-35 & 36-42\end{array}$

Experimental diet Feed intake $(\mathrm{g} / \mathrm{d})$

\begin{tabular}{|c|c|c|c|c|c|c|}
\hline $1^{1}$ & $16.28^{a}$ & $52.43^{a}$ & $79.86^{a}$ & $92.02^{a}$ & $122.12^{\mathrm{a}}$ & $152.24^{a}$ \\
\hline 2 & $16.49^{a}$ & $51.03^{a}$ & $79.06^{b}$ & $90.57^{a b}$ & $120.02^{a}$ & $150.62^{a}$ \\
\hline 3 & $16.37^{a}$ & $48.04^{b}$ & $78.53^{c}$ & $89.62^{b}$ & $119.43^{b}$ & $149.32^{b}$ \\
\hline 4 & $16.50^{a}$ & $48.97^{b}$ & $78.73^{c}$ & $88.72^{b}$ & $118.97^{b}$ & $148.25^{b}$ \\
\hline 5 & $16.31^{a}$ & $51.04^{a}$ & $79.94^{b}$ & $90.79^{a b}$ & $121.71^{a}$ & $149.25^{a}$ \\
\hline \pm SEM $^{2}$ & 0.21 & 0.27 & 0.31 & 0.49 & 0.54 & 1.31 \\
\hline
\end{tabular}

\section{P-value}

$\begin{array}{llllll}0.0001 & 0.0001 & 0.0016 & 0.001 & 0.0012 & 0.0001\end{array}$

1: 1- Control treatment: Basal diet based on corn-soybean meal without adding dried mealworm, 2- Replacement of $5 \%$ dried mealworm with Soy meal in the base diet, 3- Replacement of $10 \%$ dried mealworm with Soy meal in the base diet, 4- Replacement of 15 dried mealworm with Soy meal in the base diet and 5- Replacement of $20 \%$ dried mealworm with Soy meal in the base diet.

2: Mean error standard

Column means with common superscripts do not differ $(P>0.05)$.

Table 6 Effect of experimental diets on feed: gain of broiler chickens. 


Age (d) $\quad 1-7 \quad 8-14 \quad 15-21 \quad 22-28 \quad 29-35 \quad 36-42$

\section{Experimental diet Feed: gain}

\begin{tabular}{lcccccc}
\hline $1^{1}$ & $1.75^{\mathrm{a}}$ & $1.70^{\mathrm{a}}$ & $1.76^{\mathrm{a}}$ & $1.97^{\mathrm{a}}$ & $2.11^{\mathrm{a}}$ & $2.12^{\mathrm{a}}$ \\
\hline 2 & & & & & & \\
\hline 3 & $1.72^{\mathrm{a}}$ & $1.67^{\mathrm{a}}$ & $1.72^{\mathrm{a}}$ & $1.86^{\mathrm{b}}$ & $1.96^{\mathrm{b}}$ & $1.97^{\mathrm{b}}$ \\
\hline 4 & $1.74^{\mathrm{a}}$ & $1.69^{\mathrm{a}}$ & $1.54^{\mathrm{b}}$ & $1.83^{\mathrm{b}}$ & $1.86^{\mathrm{bc}}$ & $1.92^{\mathrm{bc}}$ \\
\hline 5 & & & & & & \\
\hline & $1.80^{\mathrm{a}}$ & $1.71^{\mathrm{a}}$ & $1.50^{\mathrm{b}}$ & $1.72^{\mathrm{c}}$ & $1.82^{\mathrm{c}}$ & $1.79^{\mathrm{c}}$ \\
& & & & & & \\
\hline \pm SEM $^{2}$ & $1.71^{\mathrm{a}}$ & $1.68^{\mathrm{a}}$ & $1.74^{\mathrm{a}}$ & $1.84^{\mathrm{b}}$ & $1.87^{\mathrm{b}}$ & $1.98^{\mathrm{b}}$ \\
& & & & & & \\
\hline
\end{tabular}

\section{P-value}

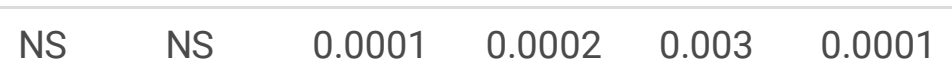

1: 1- Control treatment: Basal diet based on corn-soybean meal without adding dried mealworm, 2- Replacement of $5 \%$ dried mealworm with Soy meal in the base diet, 3-Replacement of $10 \%$ dried mealworm with Soy meal in the base diet, 4- Replacement of 15 dried mealworm with Soy meal in the base diet and 5- Replacement of $20 \%$ dried mealworm with Soy meal in the base diet.

2: Mean error standard

Column means with common superscripts do not differ $(P>0.05)$.

Table 7 Effect of experimental diets on carcass and some organs relative to the body weight of Ross 308 broilers at 21 days of age. 
$\begin{aligned} & \text { Carcass Thighs Breast Liver Heart Spleen Pancreas } \\ & \text { yeild }\end{aligned}$ Abdominal Fabricius
fat

yeild

\section{Experimental}

diets

\begin{tabular}{|c|c|c|c|c|c|c|c|c|c|}
\hline $1^{1}$ & $63.24^{c}$ & 27.14 & $28.24^{\mathrm{b}}$ & 3.12 & 0.67 & 0.10 & 0.25 & 1.32 & 0.27 \\
\hline 2 & $65.37^{b}$ & 28.52 & $28.02^{b}$ & 2.25 & 0.65 & 0.11 & 0.32 & 1.52 & 0.26 \\
\hline 3 & $66.53^{a}$ & 29.46 & $30.12^{\mathrm{a}}$ & 3.36 & 0.63 & 0.10 & 0.30 & 1.13 & 0.25 \\
\hline 4 & $66.86^{a}$ & 28.03 & $30.28^{a}$ & 3.16 & 0.65 & 0.09 & 0.29 & 1.72 & 0.26 \\
\hline 5 & $64.92^{b}$ & 27.89 & $28.68^{b}$ & 3.2 & 0.68 & 0.08 & 0.27 & 1.54 & 0.23 \\
\hline \pm SEM $^{2}$ & 0.42 & 0.53 & 0.76 & 0.05 & 0.03 & 0.04 & 0.15 & 0.08 & 0.03 \\
\hline \multicolumn{10}{|l|}{$P$ value } \\
\hline & 0.0001 & NS & 0.0012 & NS & NS & NS & NS & NS & NS \\
\hline
\end{tabular}

1: 1- Control treatment: Basal diet based on corn-soybean meal without adding dried mealworm, 2- Replacement of $5 \%$ dried mealworm with Soy meal in the base diet, 3- Replacement of $10 \%$ dried mealworm with Soy meal in the base diet, 4- Replacement of 15 dried mealworm with Soy meal in the base diet and 5- Replacement of $20 \%$ dried mealworm with Soy meal in the base diet.

Column means with common superscripts do not differ $(P>0.05)$.

2: Mean error standard

Table 8 Effect of experimental diets on carcass and some organs relative to the body weight of Ross 308 broilers at 42 days of age. 
$\begin{aligned} & \text { Carcass Thighs Breast Liver Heart Spleen Pancreas Abdominal Fabricius } \\ & \text { yeild }\end{aligned}$
fat

Experimental

diets

$\begin{array}{llllllllll}1^{1} & 65.03^{\mathrm{B}} & 30.64 & 30.43^{\mathrm{b}} & 4.25 & 1.05 & 0.17 & 0.52 & 1.13 & 0.26\end{array}$

$\begin{array}{llllllllll}2 & 64.25^{\mathrm{b}} & 31.86 & 31.01^{\mathrm{b}} & 4.19 & 1.12 & 0.18 & 0.57 & 1.25 & 0.27\end{array}$

\begin{tabular}{|c|c|c|c|c|c|c|c|c|c|}
\hline 3 & $68.10^{a}$ & 32.23 & $33.26^{a}$ & 4.54 & 1.02 & 0.16 & 0.59 & 1.33 & 0.25 \\
\hline 4 & $67.67^{a}$ & 31.57 & $32.67^{a}$ & 4.36 & 1.06 & 0.15 & 0.60 & 1.28 & 0.25 \\
\hline 5 & $65.12^{b}$ & 30.53 & $30.24^{b}$ & 5.86 & 1.07 & 0.18 & 0.56 & 1.17 & 0.24 \\
\hline$\pm \mathrm{SEM}^{2}$ & 2.26 & 2.02 & 1.12 & 0.31 & 0.06 & 0.03 & 0.05 & 0.30 & 0.03 \\
\hline \multicolumn{10}{|l|}{$P$ value } \\
\hline & 0.0012 & NS & 0.0001 & NS & NS & NS & NS & NS & NS \\
\hline
\end{tabular}

1: 1- Control treatment: Basal diet based on corn-soybean meal without adding dried mealworm, 2- Replacement of $5 \%$ dried mealworm with Soy meal in the base diet, 3-Replacement of 10\% dried mealworm with Soy meal in the base diet, 4- Replacement of 15 dried mealworm with Soy meal in the base diet and 5- Replacement of $20 \%$ dried mealworm with Soy meal in the base diet.

2: Mean error standard

Column means with common superscripts do not differ $(P>0.05)$. 